\title{
PENGARUH CITRA MEREK DAN KUALITAS PRODUK TERHADAP VOLUME PENJUALANPADA \\ PT. ASTRA INTERNATIONAL,Tbk
}

\author{
Zulharmein Pulungan, Bambang W, Vidya Fathimah \\ Alumni Sekolah Tinggi Ilmu Manajemen Sukma \\ Program studi Manajemen, Sekolah Tinggi Ilmu Manajemen \\ bambangw1204@gmail.com, vidyafathimah91@gmail.com
}

\begin{abstract}
The purpose of this study is to determine whether there is influence of brand image and product quality on sales volume at PT. Astra International Tbk-Isuzu Medan Branch. Sample This study was 129 customers who came to perform periodic maintenance from May to June 2017, sampling using random sampling that is all get the same opportunity on every member of the population to be sampled. Data analysis using multiple linear regression test with model determination (classic assumption test), hypothesis test using coefficient determination test, partial test ( $t$ test) and simultaneous test ( $F$ test), while data processing using SPSS 20, Coefficient of determination of variable of brand image and product quality able to explain its existence to sales volume variable, beside that partially brand image has no effect and not significant to sales volume while product quality have positive and significant effect to sales volume. Simultaneously the brand image and product quality are positive and insignificant to sales volume.
\end{abstract}

Keywords: Brand image, product quality and sales volume.

\section{PENDAHULUAN}

Dalam pasar yang serba kompetitif seperti sekarang ini membuat persaingan di dunia bisnis semakin tajam. Konsumen saat ini begitu dimanjakan dengan begitu banyak pilihan produk untuk memutuskan mana yang akan dibeli, sementara perusahaan dihadapkan pada persoalan yang sulit yaitu persaingan. Setiap perusahaan dituntut untuk mampu mengendalikan dan mengelola perusahaan dengan segala kemampuan dan keahlian yang ada, guna mencapai tujuan utama dan kelangsungan perusahaan.Merek mempunyai peranan penting bagi kelangsungan hidup sebuah perusahaan.

Apalagi pemasaran di masa yang akan datang lebih menjadi persaingan antar merek, yaitu persaingan untuk merebut konsumen melalui merek. Melalui citra merek yang kuat, pelanggan akan memiliki asumsi positif terhadap merek dari produk yang ditawarkan oleh perusahaan sehingga konsumen tidak akan ragu untuk membeli produk yang akan ditawarkan perusahaan. Citra merek menjadi hal yang sangat penting diperhatikan perusahaan, melalui citra merek yang baik, maka dapat menimbulkan nilai emosional pada diri konsumen, di mana akan timbulnya perasaan positif (positive feeling) pada saat membeli atau menggunakan suatu merek.

\section{Perumusan Masalah}

Berdasarkan latar belakang di atas,maka perumusan masalah dari penelitian ini yaitu:

1. Apakah citra merek berpengaruh terhadap volume penjualan PT. Astra Internasional Tbk - Isuzu Cabang Medan?

2. Apakah kualitas produk berpengaruh terhadap volume penjualan PT. Astra Internasional Tbk-Isuzu Cabang Medan? 
3. Apakah citra merek dan kualitas produk berpengaruh terhadap volume penjualan PT. Astra International Tbk-Isuzu Cabang Medan?

\section{Batasan Masalah}

Karena disebabkan keterbatasan waktu, biaya serta ilmu pengetahuan, maka penelitian ini hanya dibatasi citra merek dan kualitas produk untuk konsumen yang melakukan perawatan berkala mobil merek Isuzu PT. Astra Internasional Tbk - Isuzu Cabang Medan.

\section{Tujuan Penelitian}

Adapun tujuan dari penelitian ini adalah untuk:

1. Untuk mengetahui apakah citra merek berpengaruh terhadap volume penjualan PT. Astra Internasional Tbk - Isuzu Cabang Medan.

2. Untuk mengetahui apakah kualitas produk berpengaruh terhadap volume penjualan PT. Astra Internasional Tbk-Isuzu Cabang Medan.

3. Untuk mengetahui apakah citra merek dan kualitas produk berpengaruh terhadap volume penjualan PT. Astra International Tbk-Isuzu Cabang Medan.

\section{METODE PENELITIAN}

\section{Uji Validitas dan Reliabilitas}

Soewadji (2012: 173), "Validitas adalah persoalan yang berhubungan dengan pertanyaan sejauh mana suatu alat ukur telah mengukur apa yang seharusnya diukur". Apabila nilai uji validitas untuk tiap koesioner $>$ koefisien korelasi (r) 0,30, maka butir koesioner dinyatakan valid (Priyatno, 2013: 19).

Bila $r_{\text {hitung }}>\mathrm{r}_{\text {tabel}}$, maka butir koesioner dapat dinyatakan valid (sah)

Bila $\mathrm{r}_{\text {hitung }}<\mathrm{r}_{\text {tabel }}$, maka btir koesioner dapat dinyatakan unvalid (tidak sah)

Menurut Soewadji (2012: 184), "Reliabilitas atau tingkat ketepatan adalah tingkat kemampuan suatu alat atau instrumen penelitian dalam mengumpulkan data atau informasi yang tepat atau konsisten". Pada uji reliabilitas, teknik analisis yang digunakan yaitu teknik Cronbach Alpha. Variabel penelitian dapat dikatakan reliabel, jika nilai Cronbach Alpha> 0,60 .

\section{Metode Analisis Data}

Teknik analisi data yang digunakan pada penelitian ini, yaitu analisis statistik deskriptif .Teknik analisis data penelitian yang digunakan yaitu Regresi Linear Berganda.Regresi linear berganda digunakan karena jumlah variabel penelitian yang digunakan lebih dari dua variabel independen atau bebas. Berikut ini model regresi linear berganda, yaitu:

\section{Dimana:}

$$
\mathrm{Y}=\mathrm{a}+\mathrm{b}_{1} \mathrm{X}_{1}+\mathrm{b}_{2} \mathrm{X}_{2}+\mathrm{e}
$$

$$
\begin{array}{ll}
\mathrm{Y} & =\text { Volume Penjualan } \\
\mathrm{X}_{1} & =\text { Citra Merek } \\
\mathrm{X}_{2} & =\text { Kualitas Produk } \\
\mathrm{a} & =\text { Konstanta } \\
\mathrm{b}_{1}, \mathrm{~b}_{2} & =\text { Koefisien Regresi Penelitian } \\
\mathrm{e} & =\text { Standar Error }
\end{array}
$$

\section{Pengujian Hipotesis}

\section{a. Koefisien Determinasi $\left(\mathrm{R}^{2}\right)$}

Pada intinya uji koefisien determinasi untuk mengetahui berapa besar kemampuan model regresi variabel independen (citra merek dan kualitas produk) dapat mnjelaskan 
variabel dependen (volume penjualan). Nilai yang digunakan adalah adjusted $R^{2}$. Priyatno (2013: 100),

\section{b. Uji F (Uji Simultan)}

Pada Uji F untuk menguji signifikan pengaruh secara bersama-sama citra merek dan kualitas produk yang diterapkan perusahaan terhadap volume penjualan pada PT Astra Internasional Tbk - Isuzu Cabang Medan. Kriteria pengujian hipotesis, yaitu:

$\mathrm{H}_{0}: \mathrm{b}_{1}, \mathrm{~b}_{2}=0$ (artinya tidak terdapat pengaruh secara simultan citra merek dan

kualitas produk yang ada di perusahaan terhadap volume

pejualan pada PT Astra Internasional Tbk - Isuzu Cabang Medan).

$\mathrm{H}_{\mathrm{a}}: \mathrm{b}_{1}, \mathrm{~b}_{2} \neq 0$ (artinya terdapat pengaruh secara simultan citra merek dan

kualitas produk yang ada di perusahaan terhadap volume

pejualan pada PT Astra Internasional Tbk - Isuzu Cabang Medan).

Hal ini dilakukan dengan cara membandingkan nilai Fhitung dan Ftabel pada tingkat kepercayaan $95 \%(0,95)$. Kriteria pengujian yang digunakan, yaitu:

Bila $\mathrm{F}_{\text {hitung }}>\mathrm{F}_{\text {tabel, }}$, maka $\mathrm{H} 0$ ditolak pada signifikan $\alpha=5 \%(0,05)$. Berarti secara statistik data yang digunakan untuk menguji variabel independen (citra merek dan kualitas produk) berpengaruh terhadap nilai variabel dependen (volumen penjualan).

Bila $\mathrm{F}_{\text {hitung }}<\mathrm{F}_{\text {tabel }}$ maka $\mathrm{H} 0$ diterima pada signifikan $\alpha=5 \%(0,05)$. Berarti secara statistik data yang digunakan guna menguji semua variabel independen (citra merek dan kualitas produk) tidak berpengaruh terhadap nilai variabel dependen (volume penjualan).

\section{c. Uji-t (Uji Parsial)}

Pada uji t untuk menguji signifikan pengaruh secara parsial variabel citra merek dan kualitas produk yang diterapkan perusahaan dalam volume penjualan pada PT Astra Internasional Tbk - Isuzu Cabang Medan. Kriteria pengujian hipotesis, yaitu:

$\mathrm{H}_{0}: \mathrm{b}_{1}, \mathrm{~b}_{2}=0$ (artinya tidak terdapat pengaruh secara positif dan signifikan citra merek dan kualitas produk yang ada di perusahaan terhadap volume pejualan pada PT Astra Internasional Tbk - Isuzu Cabang Medan).

$\mathrm{H}_{\mathrm{a}}: \mathrm{b}_{1}, \mathrm{~b}_{2} \neq 0$ (artinya terdapat pengaruh secara positif dan signifikan citra merek dan kualitas produk yang ada di perusahaan terhadap volume pejualan pada PT Astra Internasional Tbk - Isuzu Cabang Medan).

Pada uji parsial, nilai yang dibandingkan yaitu $t_{\text {hitung }}$ dan $t_{\text {tabel }}$. Kriteria pengambilan keputusan, yaitu:

$\mathrm{H}_{0}$ diterima, bila $\mathrm{t}_{\text {hitung }}<\mathrm{t}_{\text {tabel }}$ pada signifikan $\alpha=5 \%(0,05)$.

$H_{0}$ ditolak ( $H_{1}$ diterima), bila $t_{\text {hitung }}>t_{\text {tabel }}$ pada signifikan $\alpha=5 \%(0,05)$.

\section{HASIL DAN PEMBAHASAN}

\section{Deskripsi data Variabel Citra Merek}

Untuk mengukur citra merek PT. Astra Isuzu Cabang Medan,digunakan sesuai dengan teori yang ada. Berdasarkan hasil pernyataan yang dijawab responden, dihasilkan sebagai berikut:

\begin{tabular}{|c|c|c|c|c|c|c|c|c|c|c|c|c|}
\hline \multirow[t]{2}{*}{ No } & \multirow[t]{2}{*}{ Pernyataan } & \multicolumn{2}{|c|}{$\begin{array}{c}\text { Sangat } \\
\text { setuju }\end{array}$} & \multicolumn{2}{|c|}{ Setuju } & \multicolumn{2}{|c|}{ Cukup } & \multicolumn{2}{|c|}{$\begin{array}{c}\text { Kurang } \\
\text { setuju }\end{array}$} & \multicolumn{2}{|c|}{$\begin{array}{c}\text { Tidak } \\
\text { Setuju } \\
\end{array}$} & \multirow[t]{2}{*}{ Jlh } \\
\hline & & $\mathbf{F}$ & $\%$ & $\mathbf{F}$ & $\%$ & $\mathbf{F}$ & $\%$ & $\mathbf{F}$ & $\%$ & $\mathbf{F}$ & $\%$ & \\
\hline 1 & $\begin{array}{l}\text { Merek Isuzu mudah } \\
\text { diingat }\end{array}$ & 47 & $36 \%$ & 47 & $36 \%$ & 28 & $22 \%$ & 4 & $3 \%$ & 3 & $2 \%$ & 129 \\
\hline
\end{tabular}




\begin{tabular}{|c|l|r|r|r|r|r|r|r|r|r|r|r|}
2 & $\begin{array}{l}\text { Merek Isuzu mudah } \\
\text { mudah diucapkan }\end{array}$ & 42 & $33 \%$ & 51 & $40 \%$ & 30 & $23 \%$ & 3 & $2 \%$ & 3 & $2 \%$ & 129 \\
\hline 3 & $\begin{array}{l}\text { Merek Isuzu mudah } \\
\text { dikenali }\end{array}$ & 43 & $33 \%$ & 55 & $43 \%$ & 17 & $13 \%$ & 9 & $7 \%$ & 5 & $4 \%$ & 129 \\
\hline 4 & $\begin{array}{l}\text { Isuzu sudah dikenal } \\
\text { banyak orang }\end{array}$ & 23 & $18 \%$ & 55 & $43 \%$ & 41 & $32 \%$ & 9 & $7 \%$ & 1 & $1 \%$ & 129 \\
\hline 5 & $\begin{array}{l}\text { Lokasi jaringan } \\
\text { penjualan Isuzu } \\
\text { mudah di jangkau }\end{array}$ & 19 & $15 \%$ & 61 & $47 \%$ & 33 & $26 \%$ & 12 & $9 \%$ & 4 & $3 \%$ & 129 \\
\hline 6 & $\begin{array}{l}\text { Isuzu memiliki fitur- } \\
\text { fitur yang modern dan } \\
\text { canggih }\end{array}$ & 43 & $33 \%$ & 52 & $40 \%$ & 17 & $13 \%$ & 12 & $9 \%$ & 5 & $4 \%$ & 129 \\
\hline
\end{tabular}

Tabel 1 Rekapitulasi jawaban responden variabel Citra Merek (x1)

Pada tabel di atas terlihat bahwa yang menjawab sangat setuju sebanyak $28 \%$,yang menjawab setuju sebanyak $41 \%$, ini menunjukkan bahwa Isuzu mudah diingat dan lokasi jaringan penjualan Isuzu mudah di jangkau, sedangkan yang menjawab kurang setuju sebanyak $21 \%$ dan yang menjawab tidak setuju sebanyak $6 \%$ serta yang menjawab sangat tidak setuju sebanyak $2 \%$, ini menunjukkan bahwa mobil Isuzu belum memiliki fitur yang canggih di bandinkan dengan mobil merek lain.

Deskripsi Variabel Kualitas Produk

Tabel 2 Rekapitulasi jawaban responden variabel Kualitas Produk(x2)

\begin{tabular}{|c|c|c|c|c|c|c|c|c|c|c|c|c|}
\hline \multirow[t]{2}{*}{ No } & \multirow[t]{2}{*}{ Pernyataan } & \multicolumn{2}{|c|}{$\begin{array}{l}\text { Sangat } \\
\text { setuju }\end{array}$} & \multicolumn{2}{|c|}{ Setuju } & \multicolumn{2}{|c|}{ Cukup } & \multicolumn{2}{|c|}{$\begin{array}{c}\text { Kurang } \\
\text { setuju }\end{array}$} & \multicolumn{2}{|c|}{$\begin{array}{l}\text { Tidak } \\
\text { Setuju }\end{array}$} & \multirow[t]{2}{*}{ Jlh } \\
\hline & & $\mathbf{F}$ & $\%$ & $\mathbf{F}$ & $\%$ & $\mathbf{F}$ & $\%$ & $\mathbf{F}$ & $\%$ & $\mathbf{F}$ & $\%$ & \\
\hline 1 & $\begin{array}{l}\text { Mobil Isuzu sudah } \\
\text { teruji ketahanan } \\
\text { mesin dan bodi }\end{array}$ & 44 & $34 \%$ & 66 & $51 \%$ & 15 & $12 \%$ & 3 & $2 \%$ & 1 & $1 \%$ & 129 \\
\hline 2 & $\begin{array}{lcc}\text { Mobil Isuzu } & \text { sudah } \\
\text { teruji di } & \text { segala } \\
\text { kondisi jalan } & \\
\end{array}$ & 30 & $23 \%$ & 82 & $64 \%$ & 7 & $5 \%$ & 5 & $4 \%$ & 5 & $4 \%$ & 129 \\
\hline 3 & $\begin{array}{l}\text { Daya tahan mesin } \\
\text { dan fisik mobil Isuzu } \\
\text { tahan lama }\end{array}$ & 34 & $26 \%$ & 76 & $59 \%$ & 10 & $8 \%$ & 5 & $4 \%$ & 4 & $3 \%$ & 129 \\
\hline 4 & $\begin{array}{l}\text { Mobil isuzu irit biaya } \\
\text { solar }\end{array}$ & 36 & $28 \%$ & 72 & $56 \%$ & 14 & $11 \%$ & 5 & $4 \%$ & 2 & $2 \%$ & 129 \\
\hline 5 & $\begin{array}{lr}\text { Jaringan perawatan } \\
\text { dan suku cadang } \\
\text { mobil Isuzu mudah } \\
\text { di jangkau }\end{array}$ & 42 & $33 \%$ & 40 & $31 \%$ & 38 & $29 \%$ & 5 & $4 \%$ & 4 & $3 \%$ & 129 \\
\hline 6 & $\begin{array}{l}\text { Perawatan berkala } \\
\text { mobil isuzu gratis } \\
\text { selama satu tahun }\end{array}$ & 36 & $28 \%$ & 72 & $56 \%$ & 13 & $10 \%$ & 5 & $4 \%$ & 3 & $2 \%$ & 129 \\
\hline & Rata-rata & & $29 \%$ & & $53 \%$ & & $13 \%$ & & $4 \%$ & & $2 \%$ & \\
\hline
\end{tabular}

Pada tabel di atas terlihat bahwa yang menjawab sangat setuju sebanyak 29\%, yang menjawab setuju sebanyak 53\%, ini menunjukkan bahwa mobil isuzu sudah teruji ketahanan mesin dan bodi serta Mobil Isuzu sudah teruji di segala kondisi jalan. Sedagkan responden yang menjawab kurang setuju sebanyak $13 \%$ dan yang menjawab tidak setuju sebanyak $4 \%$ dan yang menjawab sangat tidak setuju sebanyak $2 \%$, ini menunjukkan bahwa mobil isuzu tidak irit solar. 
Deskripsi Variabel Volume Penjualan

Tabel 3: Rekapitulasi jawaban responden variabel Volume Penjualan (Y)

\begin{tabular}{|c|c|c|c|c|c|c|c|c|c|c|c|c|}
\hline \multirow{4}{*}{ No } & \multirow{4}{*}{ Pernyataan } & \multirow{3}{*}{\multicolumn{2}{|c|}{ Sangat }} & \multirow{3}{*}{\multicolumn{2}{|c|}{ Setuju }} & \multirow{3}{*}{\multicolumn{2}{|c|}{\begin{tabular}{|l|} 
Cukup \\
\end{tabular}}} & \multirow{3}{*}{\multicolumn{2}{|c|}{$\frac{\text { Kurang }}{\text { setuju }}$}} & \multirow{3}{*}{\multicolumn{2}{|c|}{$\begin{array}{c}\text { Tidak } \\
\text { Setuju }\end{array}$}} & \multirow{4}{*}{ Jlh } \\
\hline & & & & & & & & & & & & \\
\hline & & & & & & & & & & & & \\
\hline & & $\mathbf{F}$ & $\%$ & $\mathbf{F}$ & $\%$ & $\mathbf{F}$ & $\%$ & $\mathbf{F}$ & $\%$ & $\mathbf{F}$ & $\%$ & \\
\hline 1 & $\begin{array}{l}\text { Harga produk Isuzu yang } \\
\text { dijual mengikuti harga pasar }\end{array}$ & 47 & $36 \%$ & 59 & $46 \%$ & 20 & $16 \%$ & 2 & $2 \%$ & 1 & $1 \%$ & 129 \\
\hline 2 & $\begin{array}{l}\text { Lokasi penjualan } \\
\text { perusahaan Isuzu strategis }\end{array}$ & 36 & $28 \%$ & 73 & $57 \%$ & 16 & $12 \%$ & 2 & $2 \%$ & 2 & $2 \%$ & 129 \\
\hline 3 & $\begin{array}{l}\text { Jika ada modal saya akan } \\
\text { memilih kendaraan Isuzu }\end{array}$ & 39 & $30 \%$ & 72 & $6 \%$ & 10 & $8 \%$ & 6 & 50 & 2 & $2 \%$ & 129 \\
\hline 4 & $\begin{array}{lr}\text { Memakai } & \text { kendaraan isuzu } \\
\text { memiliki } & \text { kepuasan } \\
\text { tersendiri } & \end{array}$ & 26 & $20 \%$ & 75 & $58 \%$ & 24 & 1770 & 3 & & 1 & $1 \%$ & 129 \\
\hline 5 & $\begin{array}{l}\text { Isuzu merupakan rajanya } \\
\text { kendaraan bermesin diesel }\end{array}$ & 34 & 26 & 50 & $9 \%$ & 34 & $6 \%$ & 10 & $8 \%$ & 1 & $1 \%$ & 129 \\
\hline 6 & $\begin{array}{l}\text { Isuzu bermesin diesel bahan } \\
\text { bakarnya solar lebih murah } \\
\text { dari bensin }\end{array}$ & 43 & $33 \%$ & 65 & $50 \%$ & 13 & $10 \%$ & 6 & $5 \%$ & 2 & $2 \%$ & 129 \\
\hline & Rata-rata & & $29 \%$ & & $51 \%$ & & $15 \%$ & & $4 \%$ & & $1 \%$ & \\
\hline
\end{tabular}

Pada tabel di atas menunjukkan bahwa yang menjawab sangat setuju sebanyak $29 \%$, yang menjawab setuju sebanyak 51\%, ini menunjukkan bahwa mereka akan memilih mobil Isuzu lagi karena memiliki kendaraan Isuzu merupakan kepuasan tersendiri. Sedangkan responden yang menjawab kurang setuju sebanyak $15 \%$ dan yang menjawab tidak setuju sebanyak $4 \%$ dan yang menjawab sangat tidak setuju sebanyak 1\%. Ini menunjukkan bahwa Isuzu tidak rajanya diesel, mereka memilih Isuzu bukan karena harga solar lebih murah dari bensin.

\section{Uji Validitas dan reliabilitas}

Uji validitas digunakan untuk melihat ketepatan instrument dalam penelitian. Instrument dikatakan valid jika nilai rhitung $>$ rtabel. Hasil validitas dari setiap instrument variabel penelitian adalah sebagai berikut.

Tabel 4 Validitas instrumen variabel Citra Merek

\begin{tabular}{|l|c|c|c|}
\hline \multirow{2}{*}{ Instrument } & \multicolumn{2}{|c|}{ Nilai Validitas } & \multirow{2}{*}{ Kesimpulan } \\
\cline { 2 - 2 } & rhitung & rtabel & \\
\hline Citra Merek1 & 0,449 & & Valid \\
\hline Citra Merek2 & 0,435 & & Valid \\
\hline Citra Merek3 & 0,608 & \multirow{2}{*}{0,174} & Valid \\
\hline Citra Merek4 & 0,415 & Valid \\
\hline Citra Merek5 & 0,259 & & Valid \\
\hline Citra Merek6 & 0,621 & & Valid \\
\cline { 2 - 2 }
\end{tabular}

Dari tabel 4 terlihat bahwa hasil pengujian masing-masing instrument variabel citra merek (x1) memiliki nilai rhitung $>0,174$, dengan demikian dapat disimpulkan bahwa secara keseluruhan instrument pernyataan dari variabel citra merek yang digunakan valid.

Tabel 5 Validitas instrumen variabel Kualitas Produk (x2)

\begin{tabular}{|c|c|c|c|}
\hline \multirow{2}{*}{ Instrument } & \multicolumn{2}{|c|}{ Nilai Validitas } & \multirow{2}{*}{ Kesimpulan } \\
\cline { 2 - 3 } & rhitung & rtabel & \\
\hline Kualitas Produk1 & 0,438 & 0,174 & Valid \\
\hline
\end{tabular}




\begin{tabular}{|c|c|c|}
\hline Kualitas Produk2 & 0,615 & Valid \\
\hline Kualitas Produk3 & 0,594 & Valid \\
\hline Kualitas Produk4 & 0,526 & Valid \\
\hline Kualitas Produk5 & 0,622 & Valid \\
\hline Kualitas Produk6 & 0,246 & Valid \\
\hline
\end{tabular}

Dari tabel 5terlihat bahwa hasil pengujian masing-masing instrument variabel Kualitas Produk (x2) memiliki nilai rhitung $>0,174$, dengan demikian dapat disimpulkan bahwa secara keseluruhan instrument pernyataan dari variabel citra merek yang digunakan valid.

Tabel 6 Validitas instrumen variabel Volume Penjualan (Y)

\begin{tabular}{|l|c|c|c|}
\hline \multirow{2}{*}{ Instrument } & \multicolumn{2}{|c|}{ Nilai Validitas } & \multirow{2}{*}{ Kesimpulan } \\
\cline { 2 - 2 } & rhitung & rtabel & \\
\hline Volume Penjualan1 & 0,447 & & Valid \\
\hline Volume Penjualan2 & 0,480 & & Valid \\
\hline Volume Penjualan3 & 0,614 & \multirow{4}{*}{0,174} & Valid \\
\hline Volume Penjualan4 & 0,426 & & Valid \\
\hline Volume Penjualan5 & 0,343 & & Valid \\
\hline Volume Penjualan6 & 0,395 & & Valid \\
& &
\end{tabular}

Dari tabel 4.9 terlihat bahwa hasil pengujian masing-masing instrument variabel Volume Penjualan (Y) memiliki nilai rhitung $>0,174$, dengan demikian dapat disimpulkan bahwa secara keseluruhan instrument pernyataan dari variabel citra merek yang digunakan valid.

Uji reliabilitas dilakukan untuk menjamin instrument yang digunakan berulang-ulang pada waktu yang berbeda-beda. Instrument dikatakan reliabel jika nilai cronbach alfa hitung $>$ dari cronbach alfa toleransi $(0,6)$. Hasil pengujian reliabilitas terlihat seperti berikut:

Tabel 7Hasil Reliabilitas Instrument Penelitian

\begin{tabular}{|c|l|c|c|}
\hline \multirow{2}{*}{ No } & \multicolumn{1}{|c|}{ Variabel } & Nilai & \multirow{2}{*}{ Kesimpulan } \\
\cline { 3 - 3 } & & Cronbach alfa & \\
\hline 1 & Citra Merek(x1) & 0,729 & Reliabel \\
\hline 2 & Kualitas Produk(x2) & 0,762 & Reliabel \\
\hline 3 & Volume Penjualan(Y) & 0,714 & Reliabel \\
\hline
\end{tabular}

Hasil uji reliabilitas menunjukkan bahwa nilai cronbach alfa seluruh variabel lebih besar dari 0,6, maka dapat disimpulkan bahwa kuesioner penelitian ini dikatakan reliabel.

\section{Hasil Uji Regresi Linier Berganda}

Pengujian ini dilakukan untuk mengetahui pengaruh citra merek dan kualitas produk terhadap volume penjualan Pada PT. Astra International Isuzu Cab. Medan. Berikut ini tabel hasil pengujian regresi linier berganda pada masing masing variabel yaitu :

Tabel 8 Hasil Uji Regresi Linear Berganda

\begin{tabular}{|c|c|c|c|c|c|c|}
\hline \multicolumn{7}{|c|}{ Coefficients $^{a}$} \\
\hline \multirow[t]{2}{*}{ Model } & & \multicolumn{2}{|c|}{$\begin{array}{l}\text { Unstandardized } \\
\text { Coefficients }\end{array}$} & \multirow{2}{*}{$\begin{array}{c}\text { Standardized } \\
\text { Coefficients } \\
\text { Beta } \\
\end{array}$} & \multirow{2}{*}{$\mathrm{t}$} & \multirow{2}{*}{ Sig. } \\
\hline & & B & $\begin{array}{l}\text { Std. } \\
\text { Error }\end{array}$ & & & \\
\hline \multirow{3}{*}{1} & (Constant) & 19,203 & 2,524 & & 7,609 & ,000 \\
\hline & Citra_Merek & ,025 & 073 & ,029 & 0,337 & ,737 \\
\hline & Kualitas_Produk & 183 & 078 & ,205 & 2,346 & 021 \\
\hline
\end{tabular}


Berdasarkan hasil pengujian di atas, maka diperoleh persamaan regresi linear berganda sebagai berikut:

$$
\mathrm{Y}=19,203+0,025 \mathrm{X} 1+0,183 \mathrm{X} 2
$$

Pada model regresi linear berganda diperoleh nilai kostanta volume penjualan sebesar 19,203 artinya jika nilai variabel bebas (X1 dan $\mathrm{X} 2$ ) nilainya 0 , maka variabel terikat $(\mathrm{Y})$ nilainya sebesar 19,203 . Koefisien regresi masing-masing variabel bebas bernilai positif, artinya volume penjualan dapat dipengaruhi oleh citra merek dan kualitas produk.

\section{Pengujian Hipotesis}

\section{a. Koefisien Determinasi (R2)}

Koefisien determinasi bertujuan untuk mengukur berapa besar dalam kemampuan variabel bebas dalam menerangkan variabel terikat. Nilai koefisien determinasi dapat dilihat pada tabel berikut

Tabel 9 Hasil Uji Koefisien Determinasi (R2)

\begin{tabular}{|c|r|r|r|r|}
\hline \multicolumn{5}{|c|}{ Model Summary } \\
\hline Model & $\mathrm{R}$ & $\begin{array}{c}\mathrm{R} \\
\text { Square }\end{array}$ & $\begin{array}{c}\text { Adjusted } \\
\mathrm{R} \\
\text { Square }\end{array}$ & $\begin{array}{c}\text { Std. Error } \\
\text { of the } \\
\text { Estimate }\end{array}$ \\
\hline 1 &, $\mathbf{2 0 7}$ & $\mathbf{0 4 3}$ & $\mathbf{0 2 8}$ & $\mathbf{3 , 1 4 8}$ \\
\hline
\end{tabular}

a. Predictors: (Constant), Kualitas_Produk, Citra_Merek

Nilai koefisien determinasi yang diperoleh sebesar 0,043 atau 4,3\% menunjukkan bahwa variabel citra merek dan kualitas produk mampu menjelaskan variasi yang terjadi pada volume penjualan pada PT. Astra International Isuzu Cab. Medan, sedangkan 95,7\% dijelaskan oleh variabel lain yang tidak diteliti seperti promosi dan periklanan media cetak maupun media elektronik.

b. Uji Simultan

Uji simultan (uji F) ini dilakukan betujuan untuk melihat pengaruh citra merek dan kualitas produk secara simultan terhadap volume penjualan, pengujian dilakukan pada tingkat kepercayaan 95\% atau tingkat kesalahan $\alpha=0,05$ (5\%), dengan kriteria:

1. Bila $F_{\text {hitung }}>F_{\text {tabel}}$, maka $\mathrm{H} 0$ ditolak, $\mathrm{H}_{1}$ diterima, artinya secara simultan penelitian ini berpengaruh

2. Bila Fhitung $<$ Ftabel maka $\mathrm{H} 0$ diterima, $\mathrm{H}_{1}$ ditolak, artinya secara simultan penelitian ini tidak berpengaruh.

Tabel 10 Hasil Uji Simultan

\begin{tabular}{|c|c|c|c|c|c|c|}
\hline \multicolumn{7}{|c|}{ ANOVA $^{a}$} \\
\hline \multicolumn{2}{|r|}{ Model } & $\begin{array}{c}\text { Sum of } \\
\text { Squares }\end{array}$ & df & $\begin{array}{l}\text { Mean } \\
\text { Square }\end{array}$ & $\mathrm{F}$ & Sig. \\
\hline \multirow{3}{*}{1} & Regression & 55,892 & 2 & 27,946 & 2,819 &, $063^{\mathrm{h}}$ \\
\hline & Residual & 1249,007 & 126 & 9,913 & & \\
\hline & Total & 1304,899 & 128 & & & \\
\hline
\end{tabular}

a. Dependent Variable: Volume_Penjualan

b. Predictors: (Constant), Kualitas_Produk, Citra_Merek

Berdasarkan tabel tersebut dapat dilihat bahwa nilai Fhitung yaitu 2,819 $>$ dari nilai Ftabel yaitu 2,68 dan nilai signifikan $0,063>$ dari nilai alpha 0,05 , maka keputusan yang di ambil $\mathrm{H} 0$ ditolak H1 diterima. Dengan diterimanya H1 menunjukkan bahwa variabel bebas yang terdiri dari citra merek(X1) dan kualitas produk(X2) mampu menjelaskan keragaman variabel terikat (Y). dengan demikian variabel citra merek dan kualitas produk secara simultan berpengaruh dan tidak signifikan terhadap volume penjualan pada PT. Astra International - Isuzu Cabang Medan.

c. Uji Parsial (Uji t)

Uji Parsial (Uji t) bertujuan untuk melihat pengaruh citra merek dan kualitas produk terhadap volume penjualan, dengan kriteria : 
1. Bila $\mathrm{F}_{\text {hitung }}>\mathrm{F}_{\text {tabel}}$, maka $\mathrm{H} 0$ ditolak, $\mathrm{H}_{1}$ diterima, artinya secara simultan penelitian ini berpengaruh

2. Bila Fhitung $<$ Ftabel maka $\mathrm{HO}$ diterima, $\mathrm{H}_{1}$ ditolak, artinya secara simultan penelitian ini tidak berpengaruh.

Tabel 4.14 : Hasil Uji Parsial

\begin{tabular}{|c|c|c|c|c|c|c|}
\hline \multicolumn{7}{|c|}{ Coefficients $^{a}$} \\
\hline \multirow[t]{2}{*}{ Model } & & \multicolumn{2}{|c|}{$\begin{array}{l}\text { Unstandardized } \\
\text { Coefficients }\end{array}$} & \multirow{2}{*}{$\begin{array}{c}\begin{array}{c}\text { Standardized } \\
\text { Coefficients }\end{array} \\
\text { Beta }\end{array}$} & \multirow{2}{*}{$\mathrm{t}$} & \multirow{2}{*}{ Sig. } \\
\hline & & B & $\begin{array}{l}\text { Std. } \\
\text { Error }\end{array}$ & & & \\
\hline \multirow{3}{*}{1} & (Constant) & 19,203 & 2,524 & & 7,609 & ,000 \\
\hline & Citra_Merek & ,025 & ,073 & ,029 & ,337 & ,737 \\
\hline & Kualitas_Produk & 183 & ,078 & ,205 & 2,346 & ,021 \\
\hline
\end{tabular}

a. Dependent Variable: Volume_Penjualan

Berdasarkan tabel tersebut dapat disimpulkan bahwa :

Nilai thitung untuk variabel citra merek $0,337<$ tabel 1,979 dan nilai signifikan $0,737>$ dari alpha 0,05 , Maka $\mathrm{H}_{0}$ diterima $\mathrm{H}_{1}$ ditolak demikian secara parsial variabel citra merek tidak berpengaruh terhadap volume penjualan.

Nilai thitung untuk variabel kualitas produk 2,346 $>$ ttabel 1,979 dan nilai signifikan $0,021<$ dari alpha 0,05 , Maka $\mathrm{H} 0$ ditolak $\mathrm{H} 1$ diterima demikian secara parsial variabel kualitas produk berpengaruh terhadap volume penjualan.

\section{Pembahasan}

Hasil pengujian hipotesis pertama menunjukkan bahwa variabel citra merek dan kualitas produk mampu menjelaskan variasi yang terjadi pada volume penjualan pada PT. Astra International Isuzu Cab. Medan, ini dibuktikan bahawa nilai koefisien determinasi yang diperoleh sebesar 0,043 atau $4,3 \%$ sedangkan sisanya $95,7 \%$ dijelaskan oleh variabel lain yang tidak diteliti dalam penelitian ini seperti promosi dan periklanan media cetak maupun media elektronik.

Hasil pengujian hipotesis kedua menunjukkan bahwa variabel citra merek dan kualitas produk secara simultan berpengaruh terhadap volume penjualan pada PT. Astra International - Isuzu Cabang Medan. Ini dibuktikan dengan nilai Fhitung yaitu 2,819 > dari nilai Ftabel yaitu 2,68 dan nilai signifikan $0,063>$ dari nilai alpha 0,05 . Sesuai dengan penelitian yang dilakukan Jenny Y. Ginting (2015) yang berjudul Pengaruh Citra Merek Dan Kualitas Produk Terhadap Volume Penjualan Mobil Daihatsu Xenia Pada PT. Astra International Daihatsu.

Hasil hipotesis ketiga menunjukkan bahwa secara parsial citra merek tidak berpengaruh volume penjualan sedangkan secara parsial kualitas produk berpengaruh terhadap volume penjualan. Ini dengan penelitian yang dilakukan oleh Irvandi Tamaka (2013) Citra Merek, Ekuitas Merek Dan Kualitas Produk Pengaruhnya Terhadap Volume Penjualan Pada Produk Daihatsu Di PT. Astra Internasional Daihatsu Manado.

\section{Kesimpulan}

Berdasarkan hasil penilitian dan pembahasan pada bab sebelumnya, maka dapat disimpulkan bahwa sebagai berikut :

1. Secara simultan citra merek dan kualitas produk berprngaruh positif dan tidak signifikan terhadap volume penjualan pada PT. Astra International Isuzu Cabang Medan;

2. Secara parsial variabel citra merek tidak berpengaruh dan tidak signifikan terhadap volume penjualan, sementara variabel kualitas produk berpengaruh positif dan signifikan terhadap volume penjualan;

3. Pealnggan lebih memilih produk isuzu karena mobil Isuzu sudah teruji di segala kondisi jalan. 


\section{REFERENCES}

Arikunto, S. (2013). Prosedur Penelitian (V). Jakarta: Rineka Cipta.

Cece. (2003). Analisis Hubungan Perencanaan Strategi Aliansi PDAM Tirtanadi-PT. Telekominikasi Divre I Terhadap Peningkatan Kualitas Pelayanan Pelanggan PDAM Tirtanadi... Universitas Sumatera Utara.

Dewi, W. S., Hasiolan, L. B., \& Minarsih, M. M. (2016). Pengaruh Kualitas Produk,Kepercayaan Terhadap Keputusan Pembelian Dengan Kepuasan Konsumen Sebagai Variable Intervining, 2(2).

Dinamika, S. G., \& Sari, W. V. (2015). Applied Error Analysis of Comparative Degree Sentence Construction of Students in STIM Sukma Medan. Asian EFL Journal, 5, 112-119.

Dinamika, S. G., \& Siregar, E. B. A. (2016). Developing English Syllabus for Tourism Management Students. In Proceedings of the Fourth International Seminar on English Language and Teaching (ISELT-4) (Vol. 13, pp. 16-17).

Fathimah, V. (2017). Pengaruh Perkembangan Jumlah Tabungan , Deposito dan Bagi Hasil terhadap Jumlah Pembiayaan yang Diberikan oleh Perbankan Syariah di Sumatera Utara. Jurnal Ilman, $5(1), 41-52$.

Ginting, J. Y., Harapon, S. M., \& Walangitan, M. D. (2015). Pengaruh Citra Merek Dan Kualitas Produk Terhadap Volume Penjualan Mobil Daihatsu Xenia Pada PT. Astra International Daihatsu, 3(1), 493-501.

Hidayat, A. (2013). Analisis Pengaruh Citra Merek, Kualitas Produk Dan Harga Terhadap Kepuasan Serta Dampaknya Terhadap Loyalitas Pelanggan.

Hidayat, R. (2009). Penerapan Sistem Informasi Manajemen sebagai Alat Pelaksanaan Sistem Administrasi Akademik. JURIDIKTI: Jurnal Ilmiah Pendidikan Tinggi, 2(2), 56-59.

Hidayat, R. (2010). Analisis Tingkat Penggunaan Internet Dikalangan Mahasiswa dan Hubungannya dalam Peningkatan Nilai Akademik (Studi Kasus pada Mahasiswa di Kota Medan). Jurnal Mediasi, 2(2), 55-63.

Kotler, P. (2012). Manajemen Pemasaran Perspektif Asia (Pertama). Yogyakarta: Andi.

Kotler, P., \& Amstrong, G. (2012). Prinsip-Prinsip Pemasaran (13th ed.). Jakarta: Erlangga.

Kotler, P., \& K.L, K. (2012). Marketing Management (14th ed.). New Jersey: Pearson Prestice Hall.

Masrokan, Fathoni, A., \& Minarsih, M. M. (2016). Orientation Effect Of Enterpreneurship, Marketing Knoeledge Capacity And Marketing Performance Of Marketing (Study Cace At CV. Rajawali Mas Semarang), 2(2).

Nasution, W. A. (2009). Pengaruh kepuasan kerja karyawan terhadap intensi turnover pada call center Telkomsel di Medan. Jurnal Mandiri, 4(1), 1-11.

Nasution, W. A. (2013). Pengaruh kompensasi dan lingkungan kerja terhadap kepuasan kerja karyawan pada PT. Karya Deli Stelindo Medan. Jurnal Manajemen Bisnis STIE IBBI, 20(2), 177.

Ningratri, Y. A. (2017). Analisis Pengaruh Strategi Bauran Pemasaran Jasa (3P) terhadap Keputusan Mahasiswa Memilih STIM Sukma Medan. Riset \& Ejurnal Manajemen Informatika, 3(1), 5056. 
Pamuji, D. D. (n.d.). Pengaruh Kompetensi Komunikasi Terhadap Direct Selling Serta Dampaknya Pada Volume Penjualan, 31(1), 132-139.

Prana, R. R. (2016). Analisis Faktor-faktor yang Mempengaruhi Pendapatan Asli Daerah (PAD) Kota Tebing Tinggi. Jurnal Ilman, 4(1), 74-86.

Sagita, F. E. (2013). Pengaruh Brand Image dan Harga Terhadap Keputusan Pembelian Ulang Produk Kentucky Fried Chicken (KFC) Di Cabang Bakso Grand Mall Oleh Mahasiswa Universitas Negeri Padang, 1-8.

Setiawan, U., P, P. D., \& Haryono, A. T. (2014). Pengaruh Citra Merek, Harga, Kualitas Produk Dan Gaya Hidup Terhadap Keputusan Pembelian Handphone Blackberry Gemini.

Sinaga, S., Pertiwi, L. S., Ardian, T., \& Zuhri. (2016). Inventory Simulation Optimization Under Non Stationary Demand. International Journal of Applied Engineering Research, 11(1), 524-529.

Sinuhaji, E. (2010). PENERAPAN LAYANAN UNGGUL DALAM PEMASARAN PRODUK BANK. Jurnal Mediasi, 2(1).

Sinuhaji, E. (2013). PENGARUH BUDAYA ORGANISASI TERHADAP KEPUASAN KERJA KARYAWAN PADA JASA PERHOTELAN (Studi Kasus di Garuda Plaza Hotel Medan). Bisnis Administrasi, 2(1), 2537.

Sinuhaji, E. (2014). Pengaruh Kepribadian, Kemampuan Kerja dan Motivasi Kerja terhadap Kinerja SDM Outsourcing pada PT. Catur Karya Sentosa Medan. Jurnal Ilman, 1(1), 11-22.

Soewadji, \& Jusuf. (2012). Pengantar Metodologi Penelitian (1st ed.). Jakarta: Mitra Wacana Media.

Soleh, M., \& Khusaini. (2016). pengaruh kualitas produk, citra merek dan layanan purna jual terhadap keputusan pembelian, 5, 1-18.

Sugiyono. (2012). Metode Penelitian Bisnis (Pendekatan Kuantitatif, Kualitatif, dan R\&D). Bandung: Alfabeta.

Sukendro, H. A. (2012). Pengaruh Citra Merek dan Kualitas Pelayanan terhadap Kepuasan Jama'ah pada Kelompok Bimbingan Ibadah Haji (KBIH) Indosat Medan. Universitas Terbuka.

SULISTYAWATI, P. (2012). Analisis Pengaruh Citra Merek Dan Kualitas Produk Terhadap Keputusan Pembelian Laptop Merek Acer Di Kota Semarang.

Supriyanto, \& Hidayat, R. (2010). Rancangan Sistem Informasi Administrasi Akademik berbasis Komputer. JURIDIKTI: Jurnal Ilmiah Pendidikan Tinggi, 3(3), 147-157.

Swastha, Basu, \& Irawan. (2012). Manajemen Pemasaran Modern (3rd ed.). Yogyakarta: Liberty.

Tamaka, I. (2013). Citra Merek, Ekuitas Merek Dan Kualitas Produk Pengaruhnya Terhadap Volume Penjualan Pada Produk Daihatsu Di PT. Astra Internasional Daihatsu Manado, $1(3)$.

Wardayani. (2012). ANALISIS PERBANDINGAN KINERJA KEUANGAN DITINJAU DARI SEGI PROFITABILITAS PADA PT. INDOFOOD CBP SUKSES MAKMUR. Jurnal Riset Akuntansi, $1,40-52$.

Wardayani. (2013). Pengaruh Pengetahuan Dewan Tentang Anggaran, Partisipasi Masyarakat dan Transparansi Kebijakan Publik terhadap Kinerja DPRD dalam Pengawasan Keua. Jurnal BIS-A Politeknik LP3i Medan, 2, 35-45. 
Wardayani. (2015). ANALISIS KINERJA KEUANGAN PADA PT. SIAR HARAMAIN INT. WISATA MEDAN. Jurnal Bis-A: Jurnal Bisnis Administrasi, 4(2), 14-24.

Widjanarko, B. (2015). PENGARUH PEMERIAN KOMPENSASI DAN KOMUNIKASI TERHADAP SEMANGAT KERJA KARYAWAN PADA BUMI KARYA TAMA INSURANCE CABANG MEDAN. Jurnal Research Sains, 1(2), 130-152.

Winata, E. (2015). Pengaruh Disiplin Kerja dan Budaya Kerja terhadap Semangat Kerja Karyawan pada PT. Mayasari Binangun Medan. Research Sains, 1(2), 100-117.

Winata, E. (2015). Pengaruh Pemberian Kompensasi dan Penilaian Prestasi Kerja terhadap Produktivitas kerja Karyawan pada PT. Askrindo cabang Medan. Jurnal Dunia Ilmu, 1(2).

Winata, E. (2017). ANALISA PERAMALAN PENJUALAN DAN PROMOSI PENJUALAN TERHADAP PENINGKATAN VOLUME PENJUALAN PADA PT. CAKRA ANUGERAH ARTA ALUMINDO MEDAN. Research Sains, 3(1).

Zuhri, \& Pertiwi, L. S. (2016). Airline revenue management under number of no-shows uncertainty. Global Journal of Pure and Applied Mathematics, 12(1), 1003-1012.

Zuhri. (2015). Model Input Output dan Aplikasinya pada Enam Sektor. Jurnal Ilman, 3(1), 16-21. 